\title{
Vihara Avalokitesvara : Studi Kasus Kehidupan Antar Budaya Islam Tionghoa di Banten
}

\section{Fauzaan Abdillah}

Ilmu Pemerintahan, Universitas Sultan Ageng Tirtayasa mfabdillah17@gmail.com
E-ISSN (2721-0642)

Recieved:

March 262020

Revised:

April 112020

Accepted:

April 162020

Doi Number

10.37950/ijd.v2i1.34

\begin{abstract}
The establishment of Avalokitesvara Monastery in Banten is a trace of the marriage story of Sharif Hidayatullah and Princess Ong Tien from China. Which is the Grand Mosque and Vihara is a symbol of the multiculturalism and openings of Banten community at that time to immigrants. And the existence of this research also aims to get answers to how the role of Sharif Hidayatullah in the construction of the monastery and also how the treatment of the people of Banten against minorities. The method that the author uses is the Study Library with the approach of Will Kymlicka Multicultural Cultural theory. The result is that the people of Banten are people who are able to accept openness to other realities outside them and are able to acculturate culturally and pluralally in a manner. Proven by the 5-story roof at the Great Mosque of Banten which is designed by the Chinese and the presence of the High Pacinan Mosque. In conclusion, so much the role of Sharif Hidayatullah in the construction of the monastery and prove that the people of Banten at that time have received values outside of reality or multiculturalism.
\end{abstract}

Keywords: syarif hidayatullah, multiculturalism, vihara avalokitesvara

\begin{abstract}
Abstrak
Berdirinya Vihara Avalokitesvara di Banten adalah jejak kisah pernikahan Syarif Hidayatullah dan Putri Ong Tien dari Tiongkok. Yang mana Masjid Agung dan Vihara adalah simbol dari multikulturalisme dan keterbukaan masyarakat Banten kala itu kepada pendatang. Dan adanya penelitian ini pun bertujuan untuk memperoleh jawaban atas bagaimana peran Syarif Hidayatullah dalam pembangunan vihara dan
\end{abstract}


juga bagaimana perlakuan masyarakat Banten terhadap kaum minoritas. Metode yang penulis gunakan ialah Studi Pustaka dengan pendekatan teori Kewarganegaraan Multikultural Will Kymlicka. Hasil yang didapat adalah bahwa masyarakat Banten adalah masyarakat yang mampu menerima keterbukaan terhadap realitas lain di luar mereka dan mampu berakulturasi secara budaya serta plural secara sikap. Terbukti dengan adanya atap bertingkat 5 pada Masjid Agung Banten yang di kelurahanin oleh orang Tiongkok dan adanya Masjid Pacinan Tinggi. Kesimpulannya, begitu besarnya peran Syarif Hidayatullah dalam pembangunan vihara tersebut dan membuktikan bahwa masyarakat Banten saat itu telah menerima nilai-nilai di luar realitasnya atau multikulturalisme.

Kata kunci: syarif hidayatullah, multikulturalisme, vihara avalokitesvara

\section{Pendahuluan}

Saat ini Banten adalah suatu provinsi yang terletak di ujung barat Pulau Jawa. Provinsi Banten adalah suatu tempat yang menyimpan berbagai macam cerita dan sejarah yang amat mahal yang tidak dapat di nilai dengan uang atau apapun. Banten saat ini dan Banten era kesultanan dahulu sangatlah jauh berbeda bila di nilai dari berbagai sisi. Pada perjalanannya, Banten telah beberapa kali berganti pemerintahan, di mulai dari abad 10 SM sampai abad $1 \mathrm{M}$ di era pra-sejarah yang di diami oleh orang purba Banten yang pada saat itu menganut animisme yang buktibukti pemujaannya di temukan di disekitar lereng-lereng pegunungan subur di sekitar sungai-sungai kecil di Lebak dan Pandeglang, sebagai bukti sejarah pemujaan pada Dewi Sri atau Sanghyang Pohaci yang pusat upacaranya berada di Lebak Sibedug, Citaman dan Cihunjuran, Sanghyang Dengdek dan lain-lain.

Memasuki abad ke 1 sampai 16 M masuklah Banten pada masa Kerajaan Hindu-Budha yang mulai merubah struktur sosial dan corak kerajaan. Di era ini ekspansi kerajaan Tarumanegara mulai hadir ke Banten Girang tepatnya pada abad 10 sampai 16 M. Artinya pada masa itu Banten purba berada dibawah kekuasaan Kerajaan Tarumanegara.

Menurut sejarah, Banten di zaman purba adalah suatu tempat yang di diami oleh suatu kelompok orang yang menganut animisme. Orang-orang itu adalah yang kita kenal saat ini dengan sebutan Suku Baduy yang menetap di Kelurahan Kanekes, Kecamatan Leuwidamar, Kabupaten Lebak yang sampai akhir khayatnya tetap setia menjaga tanah nenek moyangnya.

Sejarah Banten mengenai kepercayaan masyarakatnya ini terus berlanjut sampai di tahun $1529 \mathrm{M}$ atau memasuki abad $16 \mathrm{M}$ ketika Syarif Hidayatullah datang ke Banten untuk menaklukan Banten Girang yang pada saat itu di bawah kekuasaan Pucuk Umun, lebih tepatnya di bawah pengaruh Kerajaan Tarumanegara. Syarif Hidayatullah saat itu datang ke Banten untuk menyebarkan agama Islam. Dan bagi orang-orang yang pada saat itu menolak untuk di islamkan pergi ke daerah Kanekes dan membentuk kehidupan baru seperti yang kita kenal sekarang sebagai Suku Adat Baduy.

Setelah melakukan penaklukan atas Banten Girang, pusat kerajaan Banten adalah di Banten Girang, namun karena di anggap terlalu jauh dari laut yang saat itu menjadi daerah yang sangat ramai dan menjadi pusat segala kegiatan, maka di 
pindahkanlah pusat kerajaan ke Surosowan yang saat itu menjadi pusat kotanya. Alasan lain di pindahkannya pusat kota adalah karena alasan politik yaitu, karena saat itu Malaka telah di kuasai Portugis. Dari segi ekonomi pun Pelabuhan Banten adalah urat nadi pelayaran dan perdagangan di Nusantara saat itu. Pemindahan pusat kota ini adalah usul dari Syarif Hidayatullah kepada putranya Maulana Hasanuddin yang kemudian di angkat menjadi raja pertama Banten pada tahun 1522 sampai 1570.

Kesultanan Banten mencapai masa kejayaannya pada tahun 1619-1682 karena telah mampu menerapkan ekonomi politik dan mampu mengeksport lada sampai ke Eropa yang berlangsung di era Sultan Ageng Tirtayasa. Setelah beberapa puluh tahun berdiri dan banyak melakukan pembangunan, masa keemasan Banten mulai berakhir dan terjadi kehancuran sekitar tahun 1808 sampai $1832 \mathrm{M}$ yang ketika itu di pimpin oleh Sultan Muhammad Rafi'uddin (1813-1820) sebagai Raja Banten ke XVII. Pada saat itu, tahun 1684 sampai tahun 1808 adalah masa kebertuanan Belanda di Banten dan terjadi perang saudara akibat adu domba Belanda terhadap Kerajaan Banten yang menjadi awal mula kehancuran Kerajaan Banten itu sendiri. Hal ini bermula dari ditandatanganinya 'traktat lada' sebagi kompensasi bantuan VOC kepada Sultan Haji pada peperangan melawan ayahnya, Sultan Ageng Tirtayasa.

Setelah lengsernya Sultan Muhammad Rafi'uddin, Banten mengalami masa kolonialisme yakni sekitar tahun 1808 sampai tahun 1945 yang mengakibatkan rajaraja kehilangan otoritasnya dan merubah struktur sosial kala itu sampai berdampak pada kehidupan beragama karena mulai masuklah agama dan kepercayaan lain yang di bawa oleh pihak asing baik dari Belanda maupun Tiongkok serta makin ramainya Kota Surosowan akibat menjadi pusat perdagangan lada saat itu.

Menurut catatan Franco Valentijn (1858), orang Perancis yang pernah ke Banten pada tahun 1694 dan juga pembuat denah Kota Surosowan dalam lukisannya dengan judul "De Stad Bantam", jumlah penduduk kota Surosowan mencapai 30.000 sampai 40.000 orang. Dan pada tahun 1872 jumlah penduduk Banten meningkat menjadi 702.000 orang, sedangkan pada tahun 1895 tersisa 699. 185 orang. Yang terdiri atas 286 jiwa dari Eropa, 1873 jiwa dari Tiongkok, 54 jiwa dari Arab, 33 jiwa dari Timur dan 692.939 dari pribumi.

Berkurangnya jumlah penduduk Banten pada saat itu ada beberapa sebab, diantaranya : 1. Pada tahun 1879 terjadi wabah penyakit pes yang menyebabkan banyak warga meninggal 2. Meletusnya Gunung Karakatu tahun 1883 3. Terjadi perlawanan petani di Keresidenan Banten (Sartono, 1984 : 209)

Namun yang menarik dan perlu kita kedepankan dari sejarah Kerajaan Banten adalah tentang proses berdirinya dari vihara yang terletak di daerah Pabean atau Pamarican. Vihara ini terletak persis di depan Benteng Speelwijk dan sangat dekat dengan Pelabuhan Banten saat itu. Hal ini sangat menarik karena sebagaimana yang kita tahu bahwa sejak di islamkan oleh Syarif Hidayatullah penduduk Banten adalah mayoritas islam dan hanya sebagian kecil saja yang non muslim berasal dari pendatang, namun sampai ada rumah ibadah lain di tengah mayoritas muslim. Hal ini lah yang menjadi pertanyaan kita semua.

Apa yang sebenarnya terjadi dan atas dasar apa berdirinya vihara tersebut. Padahal pada saat itu, tahun 1800-an penduduk Tionghoa hanya berjumlah sekitar 1873 jiwa. Sangat jauh jumlahnya apabila di bandingkan dengan penduduk pribumi yang sangat besar yaitu 692.939 jiwa. 
Dalam sejarahnya, Banten mampu menjadi salah satu dari tiga kekuatan maritim di laut jawa selain Mataram dan VOC karena memiliki armada laut yang kuat dan mampu memanfaatkan laut sebagai sumber keuangan dengan menerapkan konsep ekonomi politiknya. Bahkan batas Kota Kerajaan Islam di Banten Lama ini, sejak 300 tahun yang lalu telah dikenal sebagai Kota Maritim Kerajaan Islam yang berkembang menjadi Kota Metropolitan dan sekaligus juga sebagai Kota Produktif (Sartono, 1977).

Bahkan di era itu, Banten bukan hanya di kenal dengan kekuatan maritimnya, namun juga sebagai penghasil atau pengeksport komoditas rempah-rempah lada yang menjadi kebutuhan dari Eropa, China bahkan Timur tengah. Hal ini di perkuat dengan catatan Tom Pires (1513) yang menyebutkan bahwa Banten telah menjadi pelabuhan kedua terpenting sesudah Kalapa (Cortesso, 1941: 168-169). Sebagai pelabuhan kedua, Banten telah menjadi pelabuhan pengekspor beras dan lada (Cortesso, 1941; Roelofsz, 1962:124). Catatan lebih terperinci didapat dari Barbosa yang menyebutkan bahwa dari pelabuhan Banten tiap tahun telah dieksport lada sebanyak seribu bahar (Chijs, 1881:4). Kemahsyuran Banten yang lain juga di kenal dengan banyaknya orang-orang yang memiliki pengetahuan dan ilmu pengobatan, salah satunya ialah Syarif Hidayatullah atau Sunan Gunung Djati yang menjadi orang yang mengislamkan setiap daerah yang di lewatinya salah satunya ialah Banten.

Menurut beberapa literatur dan jurnal-jurnal ilmiah, berkat seorang Syarif Hidyatullah atau Sunan Gunung Djati inilah di daerah Banten terdapat vihara yang berdiri kokoh hingga saat ini. Vihara itu di perkirakan mulai ada sejak tahun 1542 $M$ yang pada realitasnya lebih tua dari Masjid Agung Banten itu sendiri. Padahal sebagaimana yang kita ketahui, Syarif Hidayatullah ini adalah salah stau dari sembilan Wali Songo yang menyebarkan agama islam di Nusantara.

Di sisi lain, ada pula yang menyebutkan vihara ini di bangun pada tahun 1652 di era Sultan Ageng Tirtayasa yaitu di masa keemasan Banten. Namun apabila kita telisik lebih jauh, vihara ini tidak pernah terlepas dari nama Putri On Tien, seorang putri kaisar dari masa Dinasti Ming dari Tiongkok yang pada akhirnya menjadi istri ke-2 dari Syarif Hidayatullah atau Sunan Gunung Djati ini.

Namun pada kenyataannya, apapun realitas yang berkembang berkat beliaulah di Banten pada masa itu di bangun vihara pertama yang menjadi bukti adanya akulturasi budaya dan juga simbol perbedaan keyakinan antara Islam dan Tionghoa yang masih ada sampai sekarang ini. Hal ini menunjukan bahwa pada masa itu Banten sudah mengenal konsep kehidupan sosial multikulturalisme yang di wujudkan dalam toleransi antar umat beragama dan juga budaya yang mengakomodir nilai-nilai pluralisme, padahal dalam praktiknya bisa saja orangorang asli Banten pada saat itu dengan sifat primordialitasnya menolak bahkan tidak mengakui adanya budaya selain dari Banten dan agama Islam yang telah menjadi identitasnya.

Studi kasus mengenai berdririnya vihara ini tentunya tidak pernah bisa kita lepaskan dari adanya intrik dan lobi-lobi politik yang di bangun oleh Syarif Hidayatullah baik kepada rakyatnya secara langsung maupun kepada ulama-ulama di Banten pada saat itu. Menerima perbedaan dengan pemikiran yang sangat sederhana tentu tidaklah mudah, terlebih berada di dalam mayoritas, namun penduduk Banten pada masa itu bisa menerima dan melakukannya. 
Dalam kacamata politik tentu saja ini tidak bisa di lepaskan begitu saja dari kapabilitas simbolik seorang pemimpin yang berperan sebagai kepala pemerintahan yang adil dan di hormati rakyatnya dan memiliki pengaruh yang sangat besar sehingga mampu melobi dengan baik tanpa adanya peperangan. Setelah vihara ini di didirikan pun akan menimbulkan pertanyaan lain, yaitu bagaimana umat islam saat itu memperlakukan orang non muslim yang mana pada kenyataannya adalah minoritas.

Hal inilah yang menjadi pertanyaan mendasar sekaligus menjadi pertanyaan penelitian dari tulisan ini. Maka dengan demikian, penulis membuat rumusan masalah yaitu bagaimana pendekatan yang dibangun oleh Syarif Hidayatullah untuk mendirikan vihara dan menjaga kerukunan masyarakat Banten dengan penduduk pendatang yang bukan beragama islam tersebut.

\section{Kerangka Teori}

Karena sebagaimana yang di khawatirkan pada pemikiran yang telah terjadi di Eropa dan Amerika, terjadi perdebatan mengenai peran dan kedudukan kelompok minoritas tentang bangsa dan etnis. Persoalan ini ialah tentang ancaman tindakan otoritarian mayoritas kepada minoritas. Maka dengan demikian, penulis akan menggunakan pendekatan yang dikemukakan oleh Will Kymlicka untuk menjawab pertanyaan penelitian di atas. Kemudian sebagaimana yang di ketahui dan di pahami selama ini, konsep Multikulturalisme atau konsep mengakomodir antara suatu realitas dengan realitas lain yang berbeda sehingga akan menciptakan adanya persamaan tanpa memandang perbedaan, dalam hal ini ialah mayoritas dan minoritas. Kemudian Kymlicka membagi 2 (dua) kelompok yang akan di gunakan sebagai bahan acuan untuk menganalisis tentang minoritas, yaitu minoritas bangsa dan minoritas etnis

Minoritas bangsa biasanya lebih diskriminatif kepada suatu kelompok orang yang berasal dari suatu daerah tertentu, seperti Bangsa Asli Hawai dan Bangsa Quebec keturunan Perancis di Kanada. Jadi minoritas bangsa ialah membahasa tentang asal usul suatu kelompok secara luas, baik negara ataupun daratan. Sedangkan Minoritas Etnis ialah tentang kelompok tertentu dari suatu negara. Jadi etnis lebih spesifik daripada bangsa. Karena di dalam bangsa pasti memiliki berbagai etnis, seperti etnis Cina yang merupakan bangsa Mongolia (Kymlicka, 2002)

Kemudian untuk menjawab pertanyaan penelitian di atas, Kymlycka mengemukakan teorinya mengenai Minoritas Etnis, yaitu :

1. Hak Pemerintahan Sendiri sebagai pengakuan terhadap minoritas bangsa agar menarik batas wilayah teritorial yang jelas sehingga memiliki pemerintahan yang otonom dan mandiri dan merekapun bisa menjadi mayoritas di dalamnya. Karena pengakuan terhadap mayoritas tidak cukup hanya pada HAM, tetapi juga harus sampai kepada hak-hak politik perseorangan dan individual, tetapi juga kepada hukum dan konstitusional.

2. Hak Polietnis, adalah hak mengenai kebebasan untuk mengekspresikan diri serta unsur-unsur budayanya yang khas tanpa mengganggu kestabilan ekonomi serta politik mayoritas. Yang utama ialah hak akan pengecualian dari undang-undang yang penerapannya merugikan kelompok etnis itu sendiri, seperti bahasa, gaya hidup, agama, dan lain sebagainya. 
3. Hak Perwakilan Khusus, ialah jalan atau upaya untuk memberikan keterwakilan bagi pihak-pihak yang secara historis merasa dirugikan.

Kemudian penulis akan menjelaskan permasalahan dalam bentuk deskriptif analisis. Hal ini berarti penulis akan menggambarkan realitas multikultural di tengah masyarakat (Heywood, 2007:313). Maksudnya adalah multikulturalisme tidak mengakui adanya satu konsep mengenai yang disebut sebagai sesuatu yang baik secara tunggal, melainkan sesuatu yang baik tergantung kepada nilai pluralistik dalam masyarakat. Dengan demikian kebenaran yang disebut tunggal tidak dikenal dalam konsep multikulturalisme. Yang baik adalah yang dianggap benar oleh suatu masyarakat secara umum.

Maka penulis menggunakan landasan teori Kymlicka di atas karena dirasa sangat relevan dengan keadaan objektif di Banten pada saat itu yang sangat menerima realitas perebedaan dengan terbuka tanpa mendiskriminasi perbedan yang ada (Hikmawan, 2020), bahkan cenderung berakulturasi dengan budaya yang ada yaitu dengan hadirnya kepercayaan selain islam di sekitar tempat tinggal penduduk Banten pada saat itu yaitu yang berasal dari Tionghoa dan juga agama lain.

Hal ini lah yang menjadi fokus utama penulis dalam mengangkat tema multikultural untuk mengungkap nilai-nilai multikultural serta peran Syarif Hidayatullah sebagai tokoh Islam dan juga dikenal baik oleh masyarakat Tionghoa dalam lobi-lobi politik di bangunnya vihara di tanah Banten yang mayoritas beragama muslim serta. Studi kasus di atas pun dianggap relevan untuk di bahas karena menurut Parekh (2001), ada tiga komponen atau nilai yang mengindikasikan multikulturalisme itu sendiri, yaitu : 1. Kebudayaan 2. Pluralitas kebudayaan dan 3. Cara tertentu untuk merespons pluralitas.

Dalam penelitian ini, penulis menggunakan kerangka tujuan penulisan dari Cleere (1989) yaitu :

1. Sebagai kepentingan akademik, yaitu pendidikan

2. Kepentingan ideologi terkait identitas dan jati diri bangsa;

3. Kepentingan ekonomi yang berkaitan dengan pariwisata.

\section{Metode Penelitian}

Metode yang di gunakan dalam penelitian ini adalah Studi Pustaka. Yaitu metode untuk menjawab pertanyaan penelitian dengan sumber-sumber jawaban yang berasal dari sumber baik primer maupun sekunder serta data-data dan informasi valid yang berasal dari jurnal ilmiah, dokumen-dokumen sekunder, artikel, buku serta sumber lain yang terkait dan juga mendukung dari penelitian ini. Karena hal ini penting dilakukan dalam menjawab pokok-pokok pertanyaan. Kemudian dalam teknik pengumpulan datanya, penulis menggunakan teknik studi literasi. Yang mana data yang didapat ialah diperoleh dari jurnal ilmiah, buku, serta sumber sekunder pendukung lainnya yang valid. 


\section{Hasil dan Diskusi}

Melalui tulisan ini, penulis akan mendeskripsikan kemudian menganaisa bagaimana peran dan lobi-lobi politik yang di bangun di era Syarif Hidayatullah dalam membangun sebuah vihara dan juga bagaimana penerimaan warga pribumi Banten dalam menerima realitas perbedaan diantara meraka. Dalam sejarahnya, Vihara Avalokitesvara di bangun tahun 1652 M di era Sultan Ageng Tirtayasa. Dimana kondisi psikologis, sosial-kultural, ekonomi dan politik masyarakat Indonesia masih sangat jauh dari modernitas. Namun realitas objektif di lapangan sangat bertolak belakang dengan pemikiran dan dugaan kita.

Jika dianalisa dari realitas budaya yang di bangun serta sebagaimana struktur kuasa hirarkis monarki, bisa kita ambil sebagai hipotesa untuk menjawab pola multikulturalisme yang ada Banten kala itu. Ssetidaknya, ada 3 (tiga) model dalam penerapan multikultural dalam menghadapi pluralitas kebudayaan. Pertama adalah model yang mengedepankan substansi nasionalitas. Nasionalitas adalah suatu hal yang baru yang di sadari secara kolektif masyarakat tanpa memperhatikan aneka ragam suku bangsa, agama, dan bahasa (Hikmawan, 2020). Nasionalitas bekerja sebagai perekat integrasi antar masyarakat serta budaya. Dalam kebijakan ini setiap orang berhak untuk dilindungi negara sebagai warganegara (Hikmawan, 2020).

Yang kedua adalah model dari nasionalitas etnik yang di dasarkan pada kesadaran bersama dari etnik yang kuat, yang berlandaskan pada hubungan darah dan kekerabatan dengan para pendiri nasional. Namun begitu, model ini di anggap sebagai model yang tertutup karena orang yang berada di luar para pendiri nasional yang tidak memiliki akses dan hubungan darah langsung dengan dengan etnis pendiri negara akan tersingkir dan diperlakukan sebagai orang yang dianggap asing.

Kemudian, yang ketiga adalah yang di sebut sebagai model multikultural etnik yang secara objektif mengakui eksistensi dan juga mengakui hak-hak warga etnik secara bersama (Simamora, Hamid, \& Hikmawan, 2019). Dalam kebijakan ini, keanekaragaman yang telah menjadi realitas ialah yang harus diakui dan diakomodasi negara. Berdasarkan pemaparan di atas, bila kita bandingkan dengan pola kehidupan budaya masyarakat Banten era kesultanan, maka pola multikultural-etnik yang bisa kita jadikan rujukan sebagai awal mula dari hipotesa. Masyarakat Banten begitu menghargai realitas lain di luar identitasnya dan merekognisi kebudayaan dan juga agama yang mereka pun tak tahu siapa sebenarnya orang-orang Tionghoa itu.

Dari hal ini bisa kita buat hipotesa yaitu orang-orang Banten di era itu sebenarnya ialah sudah berada pada tahap pluralisme yang sesunguhnya. Karena jikalau mereka tidak bersikap plural, tentunya tidak akan adanya vihara yang berdiri sampai sekarang ini dan juga pada zaman sebelum di bangunnya vihara pasti adanya penolakan-penolakan dari waraga Banten saat itu.

Maka untuk masyarakat Banten sendiri, vihara ini bukan hanya tempat peribadatan dan bangunan bersejarah saja, namun juga sebagai simbol bagaimana masyarakat terdahulu menjaga keharmonisan dalam menghadapi perbedaan (Hikmawan, 2017). Hal mendasar lainnya adalah bahwa berdirinya vihara ini adalah karena seorang putri dari Tiongkok yaitu Puti Ong Tien atau Putri Tan Hong Tien Nio. Dia adalah seorang perempuan terhormat baik di negeri asalnya dan juga di tanah Banten. Hal ini di karenakan Putri Ong Tien adalah istri kedua dari Syarif 
Hidayatullah. Hal ini berawal dari Syarif Hidayatullah yang pada usai 14 belajar Agama Islam di Mesir dari para ulama di Mesir dan sempat pergi ke beberapa negara dalam hal mendalami agama.

Kemudian dalam perjalan pulangnya menuju tanah Jawa dari Mesir, beliau melakukan dakwah sekaligus menyebarkan Agama Islam pada setiap daerah yang dilaluinya termasuk daratan Tiongkok. Syarif Hidayatullah di kenal juga sbegai orang yang mempunyai kemampuan untuk mengobati dan termasuk orang yang memiliki pengetahuan yang tinggi. Hingga pada akhirnya Syarif Hidayatullah dalam menyebarkan Agama Islam sampai di daratan Tiongkok tepatnya di kota Xian yang menjadi daerah dengan jumlah pengikut islam terbanyak hingga tersebar kabar bahwa ada seorang ulama dari Jawa yang mampu menyembuhkan berbagai penyakit tanpa obat-obatan dan Syarif Hidayatullah hanya dengan melakukan gerakan Sholat.

Kemampuan Syarif tersebut dalam mengobati sampai terdengar ke dalam Istana Kaisar dan di panggillah Syarif ke Istana untuk menyembuhkan Putri Ong Tien untuk di uji kemampuannya. Tanpa di duga, Syarif mampu membuat keluarga Kaisar percaya dan meminta maaf karena telah meragukan kemampuannya. Kemudian dengan kesadaran dan keinginan Putri Ong Tien sendiri ia memutuskan untuk menyusul Syarif Hidayatullah ke Jawa untuk dipersunting dan Putri Ong Tien dikawal oleh 100 awak kapal ke Pulau Jawa. Setibanya di tanah Jawa, Putri Ong Tien tidak langsung dipersunting oleh Syarif Hidayatullah, melainkan harus masuk Agama Islam terlebih dahulu. Maka Putri pun mengikuti syariat islam tersebut dan masuk Islam. Namun tidak dengan para pengikut dan pengawal Putri, mereka tetap beragama sebagaimana yang mereka anut dari Tiongkok.

Maka dengan demikian perlu adanya tempat ibadah untuk mengakomodir pengikut dan pengawal Putri yang beragama non muslim, maka di bangunlah vihara di Pelabuhan Banten kala itu pada era Sultan Ageng Tirtayasa beberapa tahun setelah kedatangan Putri Ong Tien dan para pengikutnya. Namun pada awalnya ada penolakan yang di lakukan oleh warga Banten sendiri terhadap pembangunan vihara tersebut, karena di khawatirkan akan mempengaruhi keimanan dan dianggap mengganggu warga sekitar. Namun berkat peran Syarif Hidayatullah lah yang mencoba berbicara kepada masyarakat Banten untuk tidak memaksakan kehendak dalam beragama kepada siapapun termasuk para pendatang.

Dengan demikian, sangatlah penting peran dan figur dari Syarif Hidayatullah dalam sejarah Banten khusunya dalam berdirinya vihara ini. Karena peran beliaulah masyarakat Banten kala itu dikenalkan pada konsep multikultural. Dimana ada realitas lain selain identitas kelompok Islam ataupun budaya-budaya setempat yang hidup, melainkan ada realitas yang multidimensi yang hidup berdampingan secara sejajar dengan budaya lain.

Dalam menjalankan peran dan lobi-lobi politiknya, Syarif Hidayatullah tidak pernah terlepas dari kharismanya sebagai seorang pemimpin kerajaaan sekaligus pemimpin pemerintahan yang adil dan bijaksana. Hal ini terbukti dari kapabilitas politik yang dibangunnya, yaitu kapabilitas simbolik. Kapabilitas simbolik adalah hadirnya suatu simbol-simbol secara materil yang dipertunjukkan oleh seorang pemimpin kepada publik yang menjadi representasi dari dirinya, baik sifat maupun untuk menunjukkan kewibawannya, seperti tongkat, batu, ajimat ataupun yang lain. Sedangkan kapabilitas simbolik yang bersifat imateril ialah sifat kharismatik, 
kewibawaan, sifat bijaksana dan sebagainya (Anwar, M. Saeful, 2014)Syarif Hidayatullah dalam hal melobi masyarakat Banten menggunakan kapabilitas politik simbolik imateril, yaitu kharismatiknya dan kewibawannya untuk mengkomunikasikan perihal pembangunan vihara tersebut. Dimana sebagai seorang kepala pemerintahan sekaligus seorang sultan ia mampu mempengaruhi masyarakat dan juga tokoh-tokoh yang memiliki pengaruh di Banten kala itu.

Lantas agar Pemerintahan Kesultanan Banten berjalan dengan baik, aman dan tentram, maka sebelum Syarif Hidayatullah pergi meninggalkan Banten dan menikahi Putri Ong Tien,beliau membangun vihara untuk para pengikut Putri Ong Tien tersebut. Kemudian untuk mewujudkan Banten yang multikultural dan menjamin kehidupan masyarakatnya, diberikanlah hak pemerintahan sendiri untuk mengurusi vihara tersebut. Apabila dalam Kymlicka menyebutnya sebagai pemerintahan sendiri, maka dalam wujud yang nyata, pengikut Putri Ong Tien itu bukanlah diberi pemerintahan sendiri, melainkan sebidang tanah yang dipergunakan untuk di bangunnya vihara.

Namun vihara tersebut diandaiakan sebuah pemerintahan, karena wilayah vihara tersebut adalah privasi atau wilayah yang privat bagi selain agama yang dibawa oleh Putri Ong Tien. Maka hal itu bisa di andaikan sebagai sebuah pemerintahan yang sendiri. Demikian konsep pertama yang dikemukakan oleh Kymlicky untuk membela kaum minoritas atas ancaman dari otoritarian yang mungkin terjadi dan sejalan dengan apa yang dilakukan oleh Syarif Hidayatullah. Hal kedua yang mendukung Syarif Hidayatullah mendirikan vihara adalah karena adanya Hak Polietnis. Kymlicka menjelaskan, bahwa hak polietnis ini adalah hak yang diberikan kepada minoritas untuk kebebasan mengekspresikan diri serta budayanya tanpa mengganggu kestabilan ekonomi dan politik dari mayoritas. Pernyataan di atas di dibuktikan dengan nyata dalam arsitektur bangunan vihara ini yang memiliki gerbang depan dengan atap berhiaskan dua ekor naga yang memperebutkan mustika Sang Penerang (Matahari) sebagai simbol dalam penyambutan pengunjung dan juga jemaat di gerbang masuk utama sebelum pengunjung memasuki bangunan utama vihara.

Di dalam vihara, tepatnya di altar utama terdapat patung Dewi Kwan Im yang usianya sama dengan usia bangunan vihara. Selain itu juga terdapat patung dewa-dewa yang berada di sisi dan kanan bangunan sebanyak 16 buah dan ada juga tiang batu yang berukirkan naga. Selain menunjukkan ciri khas dari budaya dan agama Tionghoa, vihara ini juga memiliki ukiran yang menceritakan tentang kejayaan Banten Lama kala itu atau saat menjadi kota pelabuhan yang yang sangat ramai. Adapun ukiran-ukiran mengenai yang menjadi bukti dari tsunami akibat letusan gunung Krakatau yahun 1883. Bahkan terdapat juga manuskrip tiga bahasa yaitu bahasa Indonesia, Cina dan Belanda.

Ketiga, ada yang disebut sebagai Hak Perwakilan Khusus. Dalam teorinya, Kymlicka mengungkapkan bahwa hak perwakilan khusus adalah jalan atau upaya yang bisa di tempuh kepada pihak-pihak yang dirugikan secara historis. Dalam realita objektif di lapangan, hal ini pun terjadi. Adanya hak perwakilan khusus bagi warga Tionghoa ataupun bangsa lain yang datang ke Kota Surosowan saat itu. Karena sangat plural dan multikulturalnya warga Banten. Apabila kita berjalan kurang lebih 100 meter ke arah selatan dari arah vihara, kita akan menemukan Masjid Pacinan Tinggi. Masjid ini di beri nama demikian karena banyaknya orang Tionghoa yang berdagang dan tinggal di Banten kala itu, bahkan sampai menikahi 
warga pribumi. Masjid ini di bangun oleh Syarif Hidayatullah pada abad ke $16 \mathrm{M}$ atau pada tahun 1526-1570 kemudian di sempurnakan oleh Sultan Maulana Hasanudin (Amalia, 2017). Menurut sejarahnya, masjid ini adalah masjid yang pertama kali di bangun, artinya di bangun sebelum Masjid Agung Banten yang masih bisa di gunakan sampai sekarang, bahkan masjid ini adalah masjid yang menjadi wujud dari ekspresi budaya serta pengakuan budaya terhadap budaya lain dan juga terlibat dalam sejarah perkembangan islam di Banten.

Masjid ini terletak di daerah perkampungan warga Tionghoa, Kelurahan Banten, Kecamatan Kasemen uuntuk mengakomodir warga yang baru memeluk agama islam. Hal ini menunjukan bahwa tidak adanya gesekan atau konflik yang terjadi antara warga Tionghoa dan waga pribumi bahkan menjadi wujud dari rukunnya kehidupan multikultural saat itu. Dengan demikian, masjid ini menunjukan adanya pengakuan dan keterwakilan hak serta HAM kepada warga Tionghoa. Bahkan dengan ada atau tidak adanya hak keterwakilan khusus ini pun warga Banten akan tetap menerima warga pendatang yang datang ke Banten kala itu. Kemudian, masih menurut Kymlicka (1994) untuk terwujudnya kerukunan dalm setiap anggota masyarakat atau menghindari adanya permasalahan mengenai hak, sebenarnya ada dua pandangan. Pembagian ini terbagi dalam dua konsepsi hak yang di bangun oleh penggunaan titik tolak yang berbeda dalam merespon sumber dari persoalan instabilitas kultur.

Pendapat pertama merupakan reaksi atau respon atas permasalahan destabilisasi budaya yang timbul dalam kultur itu sendiri atau biasa disebut dengan intragroup-relation view (Hikmawan, 2020). Untuk menghindari lunturnya nilai-nilai kultural di dalam diri seseorang, maka perlu adanya pemenuhan hak kelompok yang diasumsikan harus berada di atas hak individu, Dengan demikian, adanya konflik horizontal di antara masyarakat dapat di minimalisir dengan harapan adanya keadilan yang bersifat kualitatif (Hikmawan, 2020).

Pandangan kedua yaitu merespon persoalan mengenai eksternal, atau yang biasa disebut juga sebagai inter-group-relation. Tekanan ekonomi dan politik dari kelompok masyarakat yang mayoritas menuntut pentingnya konsepsi mengenai hak kelompok yang sifatnya forward-looking untuk menghindari adanya subordinasi budaya (Hikmawan, 2020). Hal ini berarti dengan adanya kesetaraan warga negara yang didasarkan kepada prinsip universal atau keseluruhan dari pada hak asasi manusia, permasalahan kehidupan masyarakat dimasukan ke dalam ranah yang privat dan dibedakan dari masalah yang bersifat publik atau umum tentang keadilan (Hikmawan, 2020).

Kymlicka mempercayai bahwa dengan diberikannya kebebasan dalam kehidupan manusia untuk berekspresi yang dijamin melalui kebebasan individu. Perlindungan eksternal yang diusahakan melalui tiga hak kolektif yang dapat dibedakan, yang sejalan dengan otonomi individual melalui pinjaman akses terhadap interest kultural, ketiga hak kolektif tersebut adalah :

1. Minoritas-minoritas bangsa, kelompok masyarakat yang dengan ikatan historis pada suatu tanah air dan berpotensi memerintah sendiri

2. Minoritas-minoritas etnis, yaitu para imigran yang meninggalkan komunitas bangsa mereka dan masuk ke dalam suatu struktur masyarakat yang baru

3. Gerakan-gerakan sosial baru, semacam kelompok feminisme atau gerakan sosial yangtujuannya bersifat imateril 
Dengan kita membandingkan antara teori dan kenyataan objektif di lapangan, maka Banten kala itu atau ketika di bawah pemerintahan Syarif Hidayatullah telah melangkah menuju Multikulturalisme. Hal ini dibuktikan dengan bukti-bukti fisik seperti adanya Masjid Pacinan Tinggi, adanya hak-hak yang diberikan sebagai jaminan hidup, berdirinya Masjid Agung Banten yang memiliki corak seperti pagoda Tionghoa yaitu dengan beratap lima buah serta adanya akulturasi budaya antara warga pendatang dan juga watga lokal. Jadi jika kita klasifikasikan, secara sikap dan perlakuan yang diberikan oleh warga Banten ialah telah mempraktikan sikap Pluralisme. Menurut Susanto (2006) Pluralisme adalah secara teologis pluralitas (keragaman) agama merupakan realitas niscaya yang masing-masing berdiri sejajar sehingga semangat missionaris (dakwah) dianggap tidak relevan.

Hal ini terjadi karena dalam kondisi masyarakat yang pluralistik, semua agama dan juga budaya berada dalam titik kesetaraan (Hikmawan, 2017). Artinya tidak ada yang lebih baik dan juga yang buruk, tidak ada yang mayoritas ataupun minoritas, hal itu tentunya tidak di ungkit-ungkit kembali. Yang ada hanyalah hidup secara berdampingan dengan realitas yang ada, tidak memperdulikan asal usul serta latar belakang orang lain (Hikmawan, 2017). Kemudian, faktor-faktor yang turut menjadi krusial dalam kajian ini adalah adanya interaksi diskursif yang diwujudkan dengan dialog antar budaya dan juga antar kepercayaan. Pertukaran informasi mengenai budaya dan kepercayaan antar etnis Tionghoa membuka kesadaran kesejahteraan (Yusar, 2015).

Kerukunan dan kedamaian hidup antar umat beragama bukan berarti merelatifikasi agama-agama yang ada dengan melebur atau menyatukan kepada satu ajaran agama tertentu saja (biasa disebut sinkretisme agama) dan dengan menjadikan agama- agama yang ada itu sebagai unsur dari agama tertentu (Hikmawan, 2017). Dengan adanya kerukunan sebagaimana yang dimaksudkan adalah agar terbina dan terpeliharanya suatu hubungan masyarakat yang baik dalam pergaulan antara warganegara yang berbeda agama dan juga kepercayaan. Faktor lain yang tidak kalah pentingnya adalah yaitu dibukanya ruang-ruang pastisipasi bagi semua pihak tanpa terkecuali (Hikmawan, 2017). Dengan demikian, diharapkan kepada semua kalangan dapat berpartisipasi serta mengidentifikasi diri sebagai bagian dari pihak yang memiliki peran untuk mewujudkan perdamaian, dalam hal ini adalah pihak kesultanan, masyarakat Banten, dan juga semua pihak yang berwenang.

Hal ini penting dilakukan pada kondisi masyarakat yang multikultural untuk mengikutsertakan semua lapisan masyarakat dalam upaya konsolidasi dan juga rekonsiliasi, serta mempertegas kembali identitas masyarakat sebagai sebuah kesatuan (Hikmawan, 2020). Karena jika di jelaskan satu persatu, ada beberapa faktor yang bisa menimbulkan konflik horizontal di masyarakat, yaitu :

1. Seberapa jauh tingkat tradisionalitas dari pemikiran masyarakat atau penderitaan kolektif dari kelompok komunal tertentu jika dibandingkan dengan kelompok-kelompok lainnya

2. Ketegasan identitas dari kelompok tersebut

3. Derajat kohesi dan mobilisasi kelompok

4. Kontrol represif oleh kelompok-kelompok dominan. 
Keterkelurahankan dari adanya kerukunan antar warga adalah untuk mewujudkan kesatuan pandangan dan kesatuan sikap di masyarakat, guna melahirkan kesatuan perbuatan, tindakan serta tanggung jawab bersama antar masyarakat. Sehingga tidak ada pihak yang melepaskan diri dari tanggung jawab atau menyalahkan pihak lain. Dengan adanya kerukunan antar umat beragama yang menyadari realitas bahwa kehidupan suatu masyarakat dan negara adalah milik bersama dan menjadi tanggung jawab bersama untuk memeliharanya (Suryana 2011).

Ibrahim (2008) menyatakan bahwa "Sikap saling menerima, menghargai nilai, budaya, keyakinan yang berbeda tidak secara langsung akan berkembang sendiri. Apalagi karena dalam diri seseorang ada kecenderungan untuk mengharapkan orang lain menjadi seperti dirinya. Sikap saling menerima ini dan menghargai akan cepat berkembang bila dilatih dan dididik pada generasi muda dalam sistem pendidikan nasional". Hal ini lah yang menjadi penting bagi kita untuk dipelajari dan di terapkan sebagai hasil dari perwujudan nilai-nilai multikultural dan sikap pluralisme yang telah di terapkan sejak zaman pemerintahan Syarif Hidayatullah.

Semua agama, kepercayaan, ras, bangsa melebur menjadi satu dalam satu kota bernama Kota Surosowan kala itu. Tentu untuk mewujudkan hal ini tidaklah mudah, perlu adanya kapabilitas dari pemimpin dan juga sikap menerima dari rakyatnya. Karena menurut Charles Taylor dalam Ruth Abbey (2004) berkembang atau tidaknya suatu identitas seseorang sangatlah tergantung dari bagaimana pengakuan ataupun penolakan yang diberikan dari orang lain. Karena esensi atau inti terdalam dari wacana multikulturalisme adalah perjuangan untuk mendapatkan pengakuan (struggle for reccognition) (Hikmawan, 2020). Karena hal ini, perjuangan kelompok minoritas untuk memperhatikan identitas diri mereka dari penjajahan kelompok mayoritas, baik dalam hal agama maupun etnis (Hikmawan, 2020).

Dari studi kasus ini kita bisa membuktikan sekaligus mendapatkan hasil yang sangat objektif dan juga nyata bahwa Banten kala itu sangatlah menjunjung nilainilai multikulturalisme. Mereka sangat terbuka serta mengakui adanya realitas lain di luar realitas mereka sendiri. Banyak bukti serta jejak-jejak yang di tinggalkan oleh kebudayaan Tionghoa di Banten lama ini. Seperti Masjid Pacinan Tinggi, ukiranukiran tentang Banten yang terdapat di vihara itu sendiri, kelurahanin bangunan Masjid Agung Banten yang beratapkan 5 tingkat layaknya pagoda di Tiongkok serta jejak-jejak lain seperti masih adanya warga keturunan Tiongkok yang tinggal di sekitar vihara yang tinggal di Kampung Pacinan, Kelurahan Banten, Kecamatan Kasemens sebagai bukti dari adanya akulturasi budaya pada masa itu.

Namun yang perlu ditekankan dalam sejarah Banten ini adalah bahwa yang menajdi simbol multikulturalisme adalah Masjid Agung Banten dan juga Vihara Avalokitesvara. Bahwa dua agama ini berdampingan dan sejajar. Dalam Dita Sopia (2017), hal ini dibuktikan oleh arsitek yang membangun masjid tersebut, yaitu :

1. Raden Sepat (Arsitek yang berasal dari Kerajaan Majapahit)

2. Tjek Ban Tjut (Arsitek asal Tiongkok)

3. Hendrick Lucasz Cardeel (Arsitek dari Belanda)

Dalam catatannya, Tjek Ban Tjut ini lah yang bertugas untuk menkelurahanin atap dari Masjid Agung Banten. Dia memberikan ciri khas pada bagain atap dengan bertumpuk lima buah pada bagian utama masjid yang mirip 
dengan pagoda di Tiongkok juga meru pada pura. Adapun Hendrick Lucas adalah arsitek sekaligus muallaf asal Belanda yang bertugas membangun paviliun (tiamah) tambahan yang terletak pada sisi selataan bangunan inti maasjid dan menara mercusuar. Karena menurut Taylor, seseorang ataupun suatu kelompok akan mengalami kehancuran apabila identitasnya tidak diakui bahkan ditolak oleh masyarakat di sekitarnya. Namun begitu, usaha-usaha yang dilakukan untuk mencapai titik otentisitas diri tidak pernah sungguh-sungguh otentik, hal ini karena selalu berada dalam relasi dependen dengan identitass diri orang-orang lainnya. Maka dengan begitu ada beberapa cara yang bisa di tempuh untuk mewujudkan masyarakat yang multikultural sekaligus plural, diantaranya :

1. Adanya pemahaman dan sikap menerima satu sama lain antara mayoritas dan juga minoritas yang di wujudkan dalam bentuk sinergitas realitas

2. Adanya langkah pembaharuan dan juga langkah integrasi semua etnis dalam kehidupan masyarakat

3. Mengelola berbagai perbedaan yang ada di masayrakat yang majemuk

4. Meningkatkan kemampuan dalam interpretasi dan juga komunikasi

5. Meneladani dan juga memberi contoh yang nyata oleh pemimpin atau pemimpin agama.

\section{Kesimpulan}

Berdasarkan cacatan sejarah yang telah di deskripsikan sekaligus dianalisis, Banten Lama kala itu adalah suatu tempat yang sangat maju dan juga strategis. Letaknya sebagai pusat perdagangan dan juga pelayaran menjadikan Banten sebagai kota yang maju. Dengan demikian, perlu adanya suatu pemerintah yang bijak dan juga mengakomodir kebutuhan semua warganya, termasuk yang beragama non muslim seperti pengikut dari Putri Ong Tien. Dengan begitu, sebagai seorang istri seorang penguasa kesultanan, Putri Ong Tien bermaksud untuk mendirikan vihara yang di tujukan untuk para pengikutnya dan juga untuk menghindari konflik dengan warga lokal Banten itu sendiri.

Hal ini tentunya tidak bisa di lepaskan dari peran Syarif Hidayatullah, suami Putri Ong Tien, yang juga mampu bersikap adil dan juga bijkasana dalam mengelola pemerintahan sekaligus menjaga kerukunan masayrakatnya melalui pendekatanpendekatan dan pengakuan politik yang diberikan kepada masyarakat ataupun pendatang yang bukan beragama islam. Dengan begitu, hadirnya nilai multikulturalisme yang juga menjadi sikap bersama masyarakat Banten secara umum, yaitu pluraslisme bisa diwujudkan dengan adanya politik pengakuan yang diberikan sultan. Hal ini bisa di buktikan dengan adanya tiga buah bangunan sebagai simbol perdamaian dan wujud nyata dari hadirnya sikap pengakuan realitas lian, yaitu : Masjid Pacinan Tinggi, Masjid Agung Banten, dan juga Vihara Avalokitesvara. Maka dengan begitu, Banten bisa di katergorikan sebagai kota yang multikultural dan juga plural bagi semua masyarakat yang hadir dan tinggal disana pada masanya. Yang tak terlepas dari peran Syarif Hidayatullah dan Kesultanan Banten sebagai pemerintahan. Hal ini terjadi karena adanya partisipasi seluruh elemen masyarakat serta hubungan baik antar budaya dan agama yang terjalin berkat komunikasi yang baik, yaitu dengan syarat dilandasi komunikasi dan keterbukaan antar kedua belah pihak. Hasil penelitian menjadi penting dan 
memiliki makna untuk mengevaluasi apakah kerukunan, nilai-nilai multikultural serta sikap plural yang terjalin pada masa pemerintahan Syarif Hidayatullah bisa di pelajari sekaligus di aplikasikan pada masa sekarang ini yang kemajemukan serta mobilitasnya lebih kompleks.

\section{Referensi}

Amalia, Rizkia. (2017). "Masjid Pacinan Tinggi, Hancur atau Belum Selesai ?". Program Studi A rsitektur, Sekolah A rsitektur, P erencanaan dan P engembangan Kebijakan, Institut Teknologi Bandung.

Anwar, M. Saeful . (2014). “Kapabilitas Simbolik Politik”. Cimahi. Fakultas Ilmu Sosial Dan Ilmu Politik Universitas Jenderal Achmad Yani

Ayu, N. K. A. (2016). "Pengelolaan Kawasan Situs Kota Kuno Banten Sebagai Destinasi Wisata Budaya Untuk Meningkatkan Pergerakan Wisatawan Nusantara". Jurnal Destinasi Kepariwisataan Indonesia, Vol 2 No (2), Juni 2016

Cleere, Henry. (1989). "Introduction: The Rationale of Archaeological Heritage Management" . Dalam Henry F.Cleere (ed) Archaeological Heritage Management in theModern World (pp. 1-19). London: Unwin Hyman.

Cortesso, Armando. (1944). "The Suma Oriental of Tome Pires" . London.

Hikmawan, M. D. (2017). Pluralisme Demokrasi Politik di Indonesia. Journal of Governance, 2(2), 223-247.

https://doi.org/http://dx.doi.org/10.31506/jog.v2i2.2678

Hikmawan, M. D. (2020). Consensual Democracy: A Challenge for Differentiated Citizenship. International Journal of Innovation, Creativity and Change. www.ijicc.net (Vol. 11). Retrieved from www.ijicc.net

Heywood, Andrew. (2007). "Political Ideologies (4th Edition)" . Palgrave: McMillan.

Ibrahim. R. (2008). "Pendidikan Multikultural: Upaya Meminimalisir Konflik dalam Era Pluralitas Agama". Jurnal Pendidikan Islam El- Tarbawi No. 1. Vol. I. 2008

Irhandayaningsi, Ana. "Kajian Filosofis Terhadap Multikulturalisme Indonesia"

Kartidjo, Sartono. (1984). "Pemberontakan Petani Banten 1888". Jakarta : Dunia Pustaka Jaya

Kartidjo, Sartono (1977). "Masyarakat Kuno dan Kelompok-ekompok Sosial". Jakarta: Bhatara Karya-Akasara.

Kymlicka, W. (2002). “Kewargaan Multikulural: Teori Liberal Mengenai Hak-hak Minoritas". LP3ES,

Kymlicka, W. (1994). "Individual and Community Right" dalam buku Group Right (Juddith Barker ed.). Canada : University of Torronto Perss

M.A.P. Meiling-Roeflsz. (1962). "Asian Trade and European Influence in the Indonesian Archipelago between 1500 and about 1630" . (124)

Parekh, Bikhu. (2001). "Rethinking Multiculturalism". Harvard 
Ruth Abbey, "Timely Meditations in an Untimely Mode" dalam Ruth Abbey, ed., Charles Taylor, Cambridge: Cambridge University Press, 2004, 1

Simamora, A. R., Hamid, A., \& Hikmawan, M. D. (2019). Diskriminasi Terhadap Kelompok Minoritas Jemaat Ahmadiyah Indonesia (JAI) di Tangerang Selatan. International Journal of Demos, 1(1), 19-37. Retrieved from http:/ /hkpublishing.id/ijd-demos

Sopia, S. Dita. 2017. "Masjid Dan Vihara: Simbol Kerikunan Hubungan Antara Islam Dan Buddha (Studi Kasus Di Kelurahan Banten Kecamatan Kota Serang Provinsi Banten)" . Skripsi. Tidak Di Terbitkan. Fakultas Ushuluddin Dan Filsafat Universitas Islam Negeri Syarif Hidayatullah : Jakarta

Suryana, T. (2011). "Konsep dan Aktualisasi Kerukunan antar Umat Beragama" . Jurnal Pendidikan Agama Islam- ta'lim Vol. 9 No. 2 -2011

Susanto. E. (2006). "Pluralitas Agama: Meretas Toleransi Berbasis Multikulturalisme Pendidikan Agama" . Tadris Vol 1 No 12006.

Valenijn, F. (1858). “Valentijn, Beschrijving van Groot Djava, ofte Java Major, Amsterdam, 1796" . Ludwig Bachhofer, India Antiqua (1947:280), (253-3)

Yusar, (2015). "Ruang Publik sebagai Pendidikan kesaran Multikulturalisme" . Edutech, Tahun 14, Vol.1, No.1, Februari 2015 